\title{
Cr-rich Megacrysts of Clinopyroxene and Garnet from Lac de Gras Kimberlites, Slave Craton, Canada - Implications for the Origin of Clinopyroxene and Garnet in Cratonic Peridotites
}

\author{
Yannick Bussweiler ${ }^{1}$, D. Graham Pearson' ${ }^{1}$, Thomas Stachel' ${ }^{1}$, Bruce A. Kjarsgaard ${ }^{2}$ \\ ${ }^{1}$ University of Alberta,Edmonton, Canada, bussweil@ualberta.ca \\ ${ }^{2}$ Geological Survey of Canada, Ottawa, Canada
}

\section{Introduction}

In kimberlites, megacrysts are large crystals $(>1 \mathrm{~cm})$ of garnet, clinopyroxene, ilmenite, olivine, phlogopite, orthopyroxene, or zircon (Nixon and Boyd 1973; Mitchell 1986). Megacrysts can be subdivided into a $\mathrm{Cr}$-poor and a $\mathrm{Cr}$-rich suite, but compositional thresholds between the two have varied in different studies (Moore and Belousova 2005; Kopylova et al. 2009). In contrast to the more common Cr-poor suite (Harte 1983), megacrysts of the Cr-rich suite are enriched in $\mathrm{Cr}$ and depleted in $\mathrm{Fe}$ and $\mathrm{Ti}$ and thus are chemically indistinguishable from their peridotite equivalents (Eggler et al. 1979). Traditionally, megacrysts are assumed to crystallize from a fractionating magma near the base of the lithosphere at 150-200 km depth (Harte 1983). In this model, the Cr-poor suite is thought to crystallize first at high melt/rock ratios, whereas Cr-rich megacrysts are the product of progressing chemical interaction with the surrounding peridotite at low melt/rock ratios. The exact nature of the proposed megacryst magma and its relationship to the host kimberlite is an ongoing matter of debate (Mitchell 1986; Bell and Moore 2004; Moore and Belousova 2005). A cognate relationship between megacrysts
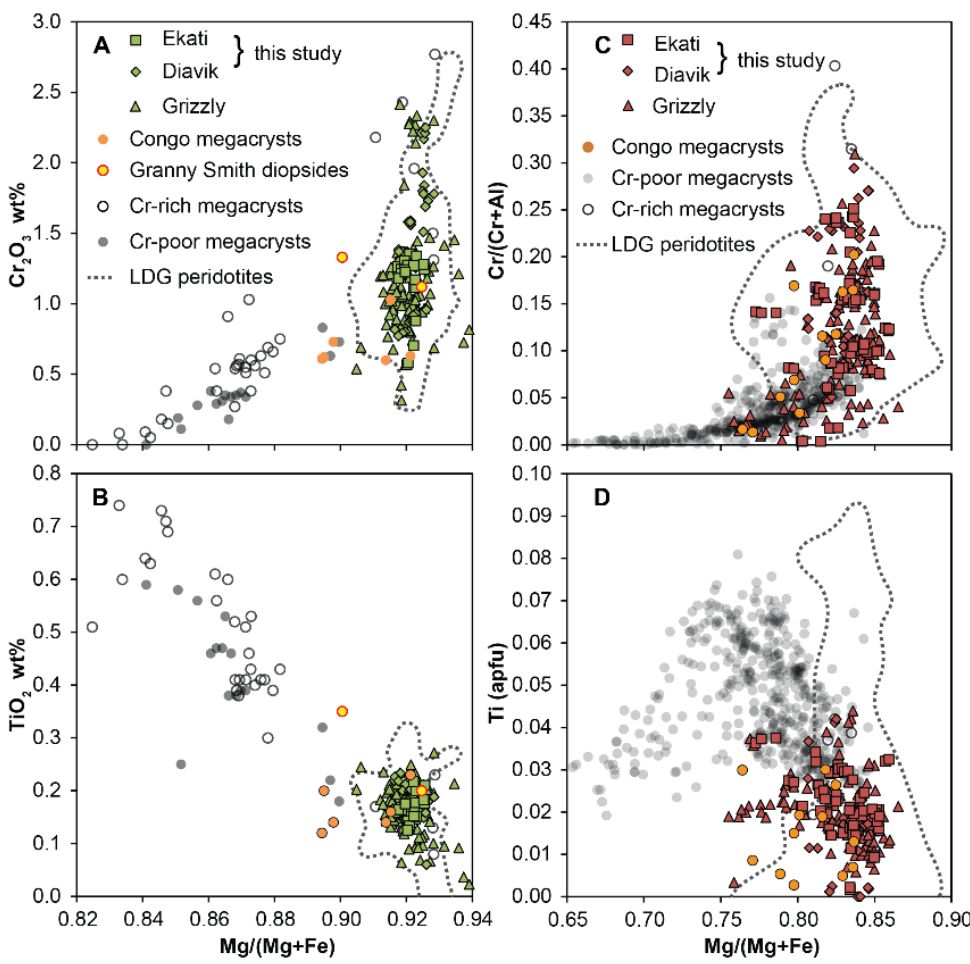

Figure 1: Major and minor element (EPMA) compositions of LDG megacrysts of $\mathrm{Cr}$-diopside clinopyroxene $(\mathrm{A}, \mathrm{B}) \mathrm{Cr}$-pyrope garnet $(\mathrm{C}, \mathrm{D})$ compared to reference data from megacrysts worldwide and phases from peridotites from Lac de Gras (LDG). and kimberlites has been questioned by isotopic studies that show disequilibrium (e.g., Hops et al. 1992; Davies et al. 2001), although other studies find greater similarity (Nowell et al. 2004; Malarkey et al. 2010). More recently, the Cr-rich suite has been interpreted to originate from multi-stage metasomatic processes, based on studies on Cr-rich megacrysts from the Jericho kimberlite, northern Slave Craton (Kopylova et al. 2009), and from the Democratic Republic of Congo (DRC) (Pivin et al. 2009). Here, we report on Cr-rich megacrysts of clinopyroxene and garnet from the Diavik and Ekati diamond mines, Lac de Gras, central Slave Craton, Canada. The Cr-rich megacrysts are interpreted to have formed from precursor kimberlite melts that stalled in the mantle and were then sampled by later kimberlites. 

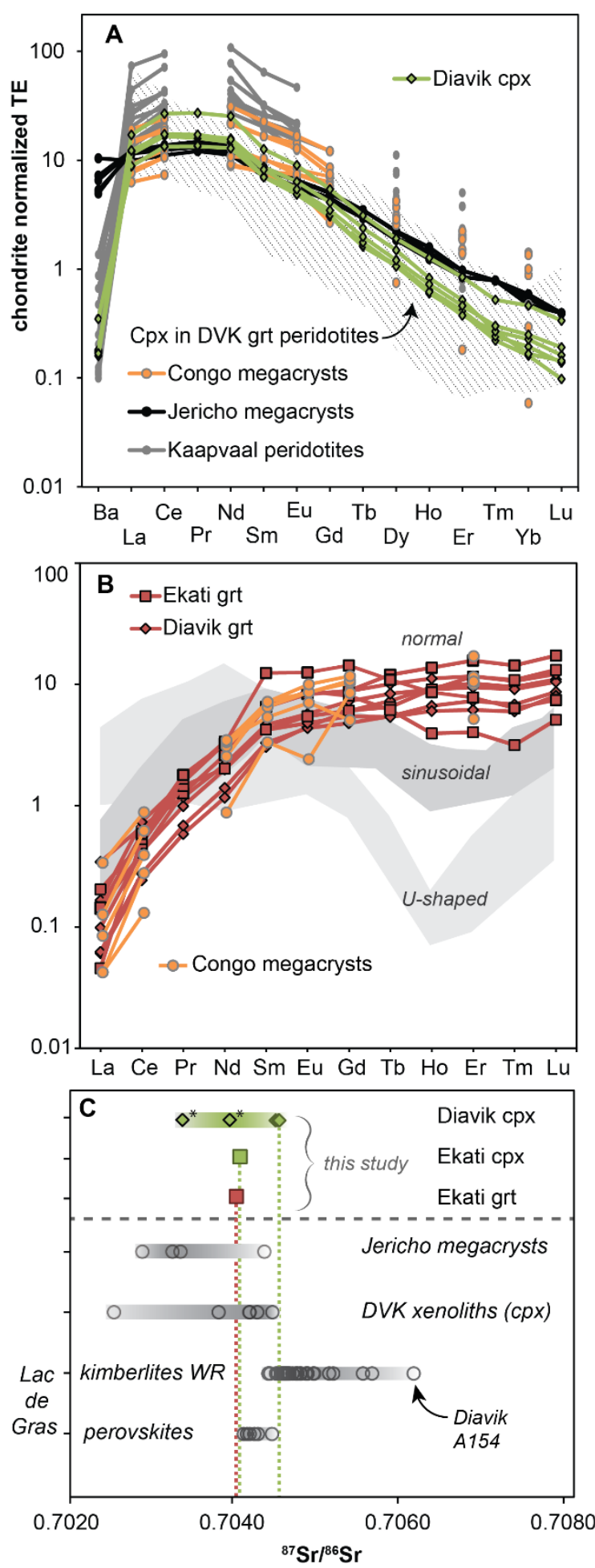

Figure 2: Trace element (LA-ICP-MS) compositions of $\mathrm{Cr}$-diopsides (A) and $\mathrm{Cr}$-pyropes (B) and $\mathrm{Sr}$ isotope (SIMS) ratios $(\mathrm{C})$ compared to reference data from megacrysts worldwide, phases from peridotite xenoliths and kimberlites from Lac de Gras.

flow is more percolative, diopsides (and pyropes) distributed throughout cratonic lherzolites may form (e.g., Simon et al. 2003). The megacrysts may be re-sampled by later kimberlites that successfully ascend to the surface. Polymineralic inclusions commonly observed in the LDG megacryst samples (Bussweiler et al. 2016) are formed during this later entrainment.

\section{Results}

No significant compositional differences between megacryst samples from the Diavik and Ekati occurrences were found in major and trace elements, and $\mathrm{Sr}$ isotopes (Figs. 1, 2). The samples are thus collectively referred to as Lac de Gras (LDG) samples. They plot at the Cr-rich and high-Mg\# end of the global megacryst trend (Fig. 1). There is consistent overlap with LDG lherzolitic phases (Aulbach et al. 2007), but also with Cr-rich megacrysts from other locations, e.g., the Jericho kimberlite (Kopylova et al. 2009) or kimberlites in the DRC (Pivin et al. 2009). In terms of trace element signatures, there is no distinction between the LDG samples, the worldwide Cr-rich megacryst suite, and clinopyroxene and garnet from LDG lherzolites (Figs. 2a, b). Their Sr isotope signatures overlap with those of typical mantle phases and are less radiogenic than the host kimberlite, but also overlap with $\mathrm{Sr}$ isotope data of primitive groundmass perovskite in LDG kimberlites (Figure 2c) (Sarkar et al. 2015). Thus, we suggest that the LDG samples described here are associated with the Cr-rich megacryst suite, and may have grown from sources that are isotopically similar to LDG kimberlites (Tappe et al. 2013).

\section{Discussion}

A plausible model combining the crystallization of the Cr-rich megacryst suite and the localized introduction of lherzolitic clinopyroxene and garnet into the surrounding mantle could involve the process of percolative fractional crystallization (Harte et al. 1993). Reaction between kimberlite-like melts, associated with a failed kimberlite, and a lithospheric mantle column is illustrated schematically in Fig. 3. This failed kimberlite may be responsible for the formation of polymict mantle breccias (Giuliani et al. 2013), possibly accompanied by crystallization of Cr-poor megacrysts (e.g., ilmenite, garnet, olivine). The crystallization of $\mathrm{Cr}$-rich megacrysts (predominantly Cr-diopside and Cr-pyrope) could occur along channel walls, where they could grow to large sizes. Further away from the channel, where the 


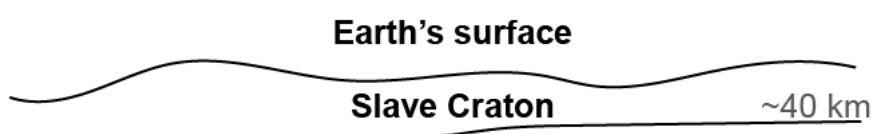

spinel
garnet

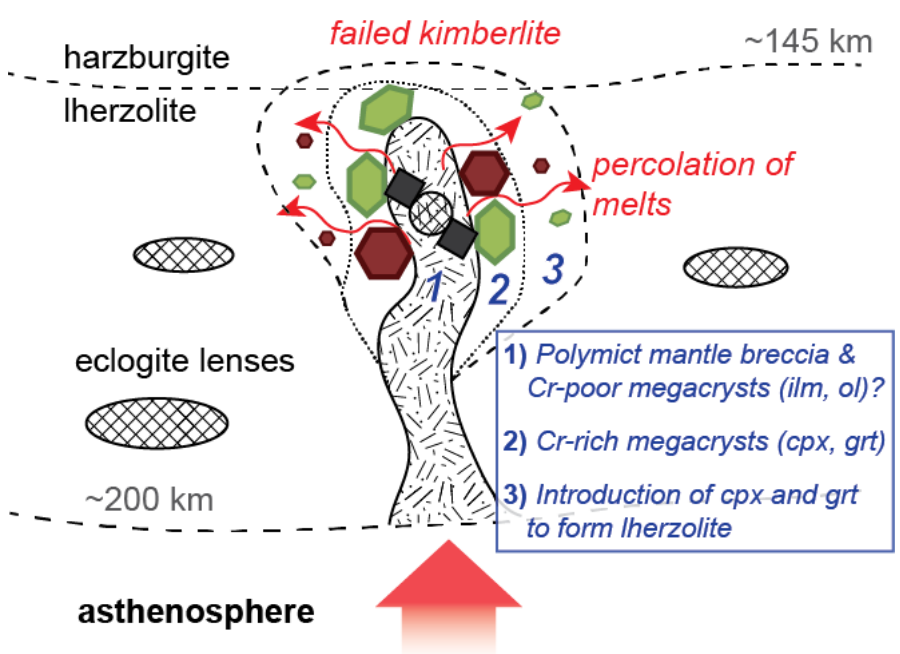

Figure 3: Schematic cartoon showing the formation of Cr-rich megacrysts from a failed precursor kimberlite melt that percolates into and crystallizes in the surrounding lithospheric mantle.

\section{References}

Aulbach S, Griffin WL, Pearson NJ, et al (2007) Lithosphere formation in the central Slave Craton (Canada): plume subcretion or lithosphere accretion? Contrib to Mineral Petrol 154:409-427.

Bell DR, Moore RO (2004) Deep chemical structure of the southern African mantle from kimberlite megacrysts. South African J Geol 107:59-80.

Davies G, Spriggs A, Nixon P (2001) A noncognate origin for the Gibeon kimberlite megacryst suite, Namibia: implications for the origin of Namibian kimberlites. J Petrol 42:159-172.

Eggler DH, McCallum ME, Smith CB (1979) Megacryst assemblages in kimberlite from northern Colorado and southern Wyoming: Petrology, geothermometry-barometry and areal distribution. Boyd Meyer 2:213-226.

Giuliani A, Kamenetsky VS, Kendrick MA, et al (2013) Oxide, sulphide and carbonate minerals in a mantle polymict breccia: Metasomatism by proto-kimberlite magmas, and relationship to the kimberlite megacrystic suite. Chem Geol 353:4-18.

Harte B (1983) Mantle peridotites and processes - the kimberlite sample. In: Hawkesworth CJ, Norry MJ (eds) Continental Basalt and Mantle Xenoliths. Shiva, Nantwich, pp 46-91

Harte B, Hunter RH, Kinny PD (1993) Melt geometry, movement and crystallization, in relation to mantle dykes, veins and metasomatism. Phil Trans R Soc Lond 342:1-21.

Hops JJ, Gurney JJ, Harte B (1992) The jagersfontein Cr-poor megacryst suite — towards a model for megacryst petrogenesis. J Volcanol Geotherm Res 50:143-160.

Kopylova MG, Nowell GM, Pearson DG, Markovic G (2009) Crystallization of megacrysts from protokimberlitic fluids: Geochemical evidence from high-Cr megacrysts in the Jericho kimberlite. Lithos 112:284-295.

Malarkey J, Pearson DG, Kjarsgaard BA, et al (2010) From source to crust: Tracing magmatic evolution in a kimberlite and a melilitite using microsample geochemistry. Earth Planet Sci Lett 299:80-90.

Mitchell RH (1986) Kimberlites: Mineralogy, Geochemistry and Petrology. Plenum Press, New York

Moore A, Belousova E (2005) Crystallization of Cr-poor and Cr-rich megacryst suites from the host kimberlite magma: implications for mantle structure and the generation of kimberlite magmas. Contrib to Mineral Petrol 149:462-481.

Nixon PH, Boyd FR (1973) The discrete nodule association in kimberlites from northern Lesotho. Lesotho kimberlites Maseru, Lesotho Natl Dev Corp 97-75.

Nowell GM, Pearson DG, Bell DR, et al (2004) Hf isotope systematics of kimberlites and their megacrysts: New constraints on their source regions. J Petrol 45:1583-1612.

Pivin M, Féménias O, Demaiffe D (2009) Metasomatic mantle origin for Mbuji-Mayi and Kundelungu garnet and clinopyroxene megacrysts (Democratic Republic of Congo). Lithos 112:951-960.

Sarkar C, Heaman LM, Pearson DG (2015) Duration and periodicity of kimberlite volcanic activity in the Lac de Gras kimberlite field, Canada and some recommendations for kimberlite geochronology. Lithos 218 219:155-166.

Simon NSC, Irvine GJ, Davies GR, et al (2003) The origin of garnet and clinopyroxene in "depleted" Kaapvaal peridotites. Lithos 71:289-322.

Tappe S, Graham Pearson D, Kjarsgaard BA, et al (2013) Mantle transition zone input to kimberlite magmatism near a subduction zone: Origin of anomalous Nd-Hf isotope systematics at Lac de Gras, Canada. Earth Planet Sci Lett 371-372:235-251. 